\title{
The Pill is Mightier Than the Sword
}

\author{
Malcolm Potts, Aafreen Mahmood, Alisha A. Graves*
}

\section{Abstract}

One determinant of peace is the role of women in society. Some studies suggest that a young age structure, also known as a "youth bulge" can facilitate conflict. Population growth and age structure are factors amenable to change in a human rights context. We propose that policies which favor voluntary family planning and the education of women can ameliorate the global burden of disease associated with conflict and terrorism. Keywords: Population, Security, Conflict, Women, Family Planning, Iran

Copyright: ๑ 2015 by Kerman University of Medical Sciences

Citation: Potts M, Mahmood A, Graves AA. The pill is mightier than the sword. Int J Health Policy Manag. 2015;4(8):507-510. doi:10.15171/ijhpm.2015.109
Article History:

Received: 19 March 2015

Accepted: 31 May 2015

ePublished: 9 June 2015

*Correspondence to:

Alisha A. Graves

Email: agraves.oasis@gmail.com
I SIS in Syria and Iraq, the Taliban in Afghanistan, and Boko Haram in Nigeria all kill and injure people. Refugees from conflict and climate change are exposed to exploitation and death. Fighting causes additional mortality and morbidity by destroying the health care systems. Today's battles differ from those in the past. At the battle of Gettysburg in 1863, 40000 men were killed or wounded but only one woman died from a stray bullet. Today, it is often women and children who suffer most from conflict. Poignantly, it is also women who hold a key to peace. The question is not, why does war break out? But, why does peace break out? We suggest that one factor in ameliorating the global burden of disease associated with conflict and terrorism is the increased role of women in society, enabled by policies related to family planning and women's education.

Rapid population growth resulting in a distorted age structure is one of many factors associated with civil unrest and violence. Others include persistent poverty, repressive governance, food shortages, global economy, resource consumption, and extreme interpretations of religion. We argue that the biological, economic, and sociopolitical ramifications of the "youth bulge" resulting from rapid population growth are primary contributors to political conflict and terrorism - especially in environments with inadequate job opportunities. These ramifications warrant research attention and programmatic investment because they are most amenable to change from a human rights perspective through voluntary family planning and girls education.

\section{The Biology of Violence}

The overwhelming majority of soldiers, terrorists, criminals, European football hooligans, political radicals, rock stars, outstanding mathematicians, highest automobile insurance premium payers are men in the 15 to 29 years old age group. Men in their twenties also possess the highest testosterone levels, ${ }^{1}$ which are associated with dominance ${ }^{2}$ and competition. Relative to married men at the same age, unmarried men have higher testosterone levels and are three times as likely to murder someone. ${ }^{3}$ Testosterone levels rise during competitive sports for both male players and fans even among old men playing dominoes. ${ }^{4}$ High testosterone levels are also correlated with hedge fund managers' risk taking on Wall Street. ${ }^{5}$

\section{The Demography of Violence}

Populations with a low median age are often more conflictdriven than those with a higher median age. Of the 800000 people murdered in 100 days in 1994 Rwanda, half of all adult men were in the 15 to 29 age cohort. In war torn Liberia the mean age of the population is 17 , as opposed to 35 in the United States. In Pakistan and Afghanistan, $44 \%$ to $47 \%$ of all adults belong to this volatile age group. The 9/11 Commission Report points out how:

"'High birth rates...throughout the Moslem world' have produced 'a large, steadily increasing population of young men without any reasonable expectation of suitable or steady employment - a sure prescription for social turbulence."'6

Mesquite and Weiner found the ratio of younger to older men accounted for about one-third of the variance in war and terrorism occurrences. ${ }^{7,8}$ While this may indicate a compelling relationship in social science terms, the impact of this 'youth bulge' is context-specific. In a socially homogenous society, such as South Korea or Taiwan, a youth bulge can help drive economic growth. ${ }^{9,10}$ However, a youth bulge can facilitate conflict in societies with ethnic and/or religious divisions, lack of education, employment opportunities, and healthcare. In Sri Lanka, Sinhalese political radicalism began in the 1950s and 60 s as the ratio of men ages 15 to 29 exceeded $20 \%$ of the total Sinhalese population. The minority Tamil population's violent response in the 1980s occurred precisely when the ratio of younger men to the total population of Tamils also 
exceeded $20 \% .^{11}$

Other factors skewing the population structure can also correlate with violence. In 19th century China, widespread female infanticide skewed the sex ratio as high as 129 males to 100 females. Unmarried men often formed bands of vagabonds. ${ }^{12}$ By contrast, in mid-nineteenth century England and Wales, many men had emigrated to the colonies and for the first time in history, 500000 women did not marry and were not swept into a life of continuous child-rearing. Worsnop argues that these unmarried women were a driving force in establishing the professions such as nursing, making higher education accessible to women, and ultimately sparked calls for female equality. ${ }^{13}$

\section{The Case of Syria}

The United Nations (UN) has declared Syria's ongoing civil war as the "worst humanitarian crisis" with estimates of over 200000 dead, millions displaced in refugee camps, sectarian violence, and a broken healthcare system. ${ }^{14}$ The Assad regime's failure to respond to extreme drought conditions and exploitative irrigation policies for government cronies left over 800000 young, poor farmers unemployed..$^{15}$ As unemployed farmers migrated with their families to Syrian cities, resources, education, and employment opportunities for the large incoming youth population were further strained. The Assad regime's silencing of dissent, coupled with sectarian conflict, diminishing resources, ammunition from surrounding countries, and a fast-growing population eventually culminated in the Syrian revolution. ${ }^{15}$ Five years of Syria's civil war have pulled thousands of young men into violence as a means of achieving economic security and political inclusion. Syrian women fleeing this violence suffer disproportionately in refugee camps, where they lack access to basic contraception. ${ }^{14}$ As a result, refugee camps are experiencing a rising incidence of unintended pregnancies and pregnancy complications. ${ }^{14}$

\section{Connecting the Dots}

During the Eisenhower administration, General William H. Draper Jr. emphasized the strategic significance of rapid population growth. Draper Jr. crafted many aspects of United States and international family planning assistance. In 1974, Henry Kissinger's National Security Memo 200 suggested expanding US aid assistance to international family planning. Vatican pressure has been credited with blocking the implementation of key recommendations. ${ }^{16}$ Forty years and 3.3 billion additional people later, the British Ministry of Defense argues that its military should understand demography and the importance of investing in women. ${ }^{17}$ The Foreign Affairs Committee of the UK Parliament, chaired by Sir Richard Ottaway, concluded:

"There is clear evidence that in many cases, high population growth in the developing world tends to correlate to political instability and to the spread of radical or extremist views...."17

\section{Women's Empowerment}

Women's empowerment - or women's freedom to make choices about their bodies and their lives - is fundamental for peace. Though African women are doing the majority of agricultural work, they are only given control over a small minority of capital resources. Each year, over 14 million girls under age 18 are married, many against their will. ${ }^{18}$ In Afghanistan, the Taliban even deny women access to a male doctor when complications arise in pregnancy. In 2012, Hudson et al, in a careful quantitative study confirmed that measures of the "the physical security of women [in a society] is strongly associated with the peacefulness of the state." 19 Investing in girls' education may be the most leveraged and cost effective investment a region in turmoil can make. Among other benefits, educated girls tend to marry later and have fewer children. Education, for good reason, is considered the primary driver of social and economic development. Nonetheless, Pakistan spends only $2.2 \%$ of its gross domestic product (GDP) on education for its exploding population, leaving it with only approximately 30000 madrassas, or religious schools, as sources for knowledge. Educating its 30 million illiterate women would cost the Pakistani government approximately two billion dollars. By comparison, the new Joint Strike Fighter program costs about $\$ 200$ billion - only to be used a few times in a shooting war, as opposed to education which lasts a lifetime.

\section{Access to Family Planning}

Access to family planning has a powerful impact on birth rates. ${ }^{20-25}$ Family size falls when women have the knowledge and means to separate sexual intercourse from childbearing. It is a common sense assertion, but often overlooked by influential economists and development strategists. Without use of contraception, the default position in any heterosexual partnership is a large family. Deciding on the size of one's family depends on a conscious, persistent and often difficult effort to turn off fertility.

Children in small families are more likely to enter school and stay in school than children in large families. ${ }^{26}$ In countries where the birth rate has fallen, children graduating from school are more likely to be employed as adults. In Egypt, 800000 young people enter the job market annually; however, the unemployed young men are called hayateen - "men who lean against walls." They are tinder for extreme political teachings and fundamentalist religious sects. Falling family size pays an economic "demographic dividend,", 10 at the national level, as savings rates increase when family size decreases. The "Asian tigers," such as Korea, Taiwan, and Singapore, have small families because in the 1960s their governments instituted organized family planning programs as a strategy to escape from poverty.

In countries where the couples' desire to control their family size has been met with access to family planning, the birth rate has almost always fallen. ${ }^{23}$ Thailand and the Philippines have had the same population size since 1950. Thailand made contraception and safe abortion widely available, thereby decreasing the average number of children in a family from 6 to 1.8. In the Philippines, religious barriers often prevent women from accessing contraception. Today, the average family has 3 children and the population is 96 million. Over time, a seemingly small difference in family size makes a 
significant overall difference in population size. In 2050, Thailand is expected to have 61 million people and become a prosperous, democratic country. Without a major shift in population growth regulation policies and related services, the Philippines will have about 157 million people. This growth will outstrip the country's ability to provide basic services and jobs, which we predict will ultimately lead to poverty and political instability.

Unfortunately, in countries covering more than half of the world's population, the range of family planning methods offered remains limited. Low-income women in developing countries face a great many unjustified barriers that often stand between them and accessing the fertility regulation technologies they need. ${ }^{27}$ For example, medical traditions commonly require women to attend a family planning clinic on the day she is menstruating in order to demonstrate that she is not pregnant. Barriers to family planning are a tangle of such details and often result in women having larger families than they desire.

\section{The Experience of Iran}

The Islamic Republic of Iran has seen the most rapid decline in birth rates than any country on the planet. In the late 1980s, informed decision-makers understood that rapid population growth was outpacing growth in the GDP - a recipe for increased poverty. The religious leadership endorsed family planning on health grounds, Iran manufactured its own oral contraceptives and condoms, and offered vasectomies and female sterilization. Before young couples could marry, they were required to receive family planning instruction. In the decade 1986 to 1995, family size in Iran fell from 5.6 to 3.3 children, and today it stands at 1.8. There are now more women than men in Iranian universities. However, a draconian new Comprehensive Population and Exaltation Family Bill aims to lower the age of marriage and outlaw voluntary sterilization. In 2013, over 270000 girls aged 10 to 19 were married and several births to girls aged 10 were registered. ${ }^{28}$

\section{Conclusions}

Family planning is about responding to what women want, and not telling them what to do. Just as forced or coercive contraception is cruel and unacceptable, so is forced pregnancy and childbearing due to lack of family planning. Family planning is natural and essential for modern living, as it allows societies to reach economic prosperity, security, and achieve sustainable population growth. Effective use of family planning can prevent skewed age structures that result in the "youth bulge," which - among various external factors - is a precursor for violence. We invite others to examine further empirical evidence for this view and recommend that security experts consider girls education, family planning, and youth employment among their strategies. Through ensuring women the freedom and resources to make informed decisions about their body and family size, we expect to find that the pill is mightier than the sword.

Ethical issues

Not applicable.
Competing interests

Malcolm Potts, physician and biologist, is Professor of Maternal and Child Health in the School of Public Health, University of California (UC), Berkeley, CA, USA. He is author of "Sex and War: How Biology Explains Warfare and Terrorism". Alisha Ann Graves, is Vice-President, Population Programs at Venture Strategies for Health and Development. Together, they started and lead the Organizing to Advance Solutions in the Sahel (OASIS) Initiative, a project of UC Berkeley. Aafreen Mahmood is a rising senior at UC Berkeley, majoring in Public Health and minoring in Global Poverty and Practice.

Authors' contributions

MP wrote the majority of the paper. AM wrote the section "the Case of Syria." AAG wrote the sections "Women's Empowerment" and "Access to Family Planning" and did the majority of revisions.

\section{References}

1. Ganong WF. Review of Medical Physiology. Los Altos, CA: Lange; 1967.

2. Mazur A, Booth A. Testosterone and dominance in men. Behaviroal and Brain Sciences. 1998;21(3):353-363. doi:10.1017/s0140525×98001228

3. Mazur A, Michalek J. Marriage, divorce and male testosterone. Social Focus. 1998;77(1):315-330. doi:10.2307/3006019

4. Mazur A, Booth A, Dabbs JM. Testosterone and chess competition. Society, Psychiatry Quarterly. 1992;55(1):70-77. doi:10.2307/2786687

5. Apicella CL, Dreber A, Campbell B, et al. Testosterone and financial risk taking. Evolution and Human Behavior. 2008;29:384-393. doi:10.1016/j.evolhumbehav.2008.07.001

6. The 9/11 Commission Report: Final Report of the National Commission on Terrorist Attacks upon the United States. New York; WW Norton \& Company; 2004.

7. Mesquite CG, Weiner NI. Human collective aggression: a behavioral ecology perspective. Ethnology and Sociobiology. 1996;17:247-262. doi:10.1016/0162-3095(96)00035-0

8. Mesquite CG, Weiner NI. Male age composition and severity of conflicts. Politics Life Sci. 1997;18:181-189.

9. Bank TW. Population change and economic development. Oxford: Oxford University Press; 1984.

10. Birdsall N, Kelley AC, Sinding SW, eds. Population Matters: Demographic Change, Economic Growth, and Poverty in the Developing World. Oxford University Press: Oxford; 2001.

11. Fuller G. The Demographic Backdrop of Ethnic Conflict. Washington, DC: CIA; 1993.

12. Hudson VM, Boer AD. A surplus of men: a deficit of peace: security and sex ratios in Asia's largest states. Int Secur. 2002;26(4):5-38. doi:10.1162/016228802753696753

13. Worsnop J. A Reevaluation of "the problem of surplus women" in nineteenth century England. Womens Stud Int Forum. 1990;13(1-2):21-31. doi:10.1016/0277-5395(90)90071-5

14. Idris M. Syrians flee violence and disrupted health services to Jordan. Bull World Health Organ. 2013;91:394-395. doi:10.2471/ blt.13.020613

15. Hinnebusch R. Syria: from 'authoritarian upgrading' to revolution? IntAff. 2012;88:95-113. doi:10.1111/j.1468-2346.2012.01059.x

16. Mumford SD. The Life and Death of NSSM 200: How the Destruction of Political Will Doomed a U. S. Population Policy. Research Triangle Park, North Carolina: Center for Research on Population; 1996

17. United Kingdon Foreign Affairs Committee. The United Kingdom's response to extremism and instability in North and West Africa; 2014.

18. United Nations Population Fund 2012. Marrying Too Young; End Child Marriage. New York: United Nations Population 
Fund; 2012.

19. Hudson VM, Ballif-Spanvil B, Capriolo M, Emmett CF. Sex \& World Peace. New York; Colombia University Press; 2012

20. Phillips JF, Ross JA, eds. Family Planning Programs and Fertility. Oxford: Clarendon Press; 1997.

21. Bank TW. Effective Family Planning Programs. Washington, DC: The World Bank; 1993.

22. Seltzer JR. The Origins and Evolution of Family Planning Programs in Developing Countries. Santa Monica, CA: RAND; 2002.

23. Potts M. Sex and the birth rate: demographic change, and access to fertility regulation methods. Popul Dev Rev. 1997;23:1-40. doi:10.2307/2137459

24. Potts M. The Unmet Need for Family Planning. Scientific
American; 2000.

25. Bongaarts J, Bruce J. The causes of unmet need for contraception and the social context of services. Stud Fam Plann. 1995;26:5775. doi: $10.2307 / 2137932$

26. Knodel J, Havanon N, Sittitrai W. Family size and the education of children in the context of rapid fertility decline. Popul Dev Rev. 1990;16(1):31-62. doi:10.2307/1972528

27. Ross J. The Question of Access. Stud Fam Plann. 1995;26:241242. doi:10.2307/2137849

28. Amnesty International. You Shall Procreate: Attacks on Women's Sexual and Reproductive Rights in Iran. https://www.amnesty. org/en/documents/mde13/1111/2015/en. Published March 11, 2015. 